\title{
KARAKTERISTIK PEREDAMAN GETARAN KONSTRUKSI MODEL JEMBATAN UNTUK PENGEMBANGAN SISTEM DIGANOSIS POLA GAGAL
}

\author{
Susilo Adi Widyanto ${ }^{1}$, Achmad Widodo ${ }^{2}$ Kamta $^{3}$, Agus Suprihanto ${ }^{4}$, \\ Faisal Yusuf Tornado ${ }^{5}$, Canggih Nugroho ${ }^{6}$ \\ Jurusan Teknik Mesin ${ }^{1,2,4,5,6)}$, Jurusan Teknik Sipil' ${ }^{3)}$, Universitas Diponegoro \\ Jl. Prof. Sudarto, SH, Tembalang, Semarang, 40277 \\ Email: susilo70@yahoo.com ${ }^{I}$
}

\begin{abstract}
In operation, the bridge structure is subjected to load variation both in the form of static load and dynamic load in variation of load intensity and frequency. In bridge structures made of steel structures, dynamic loading conditions can cause loosening of bolts, cracks and even structural failures. This paper describes the method of determining the damping bridge constant (c) by the logarithmic decrement calculation method of the vibration data generated by the impulse load. Furthermore the damping constant is used to calculate the vibration response equation of the structure along with the mass constant $(m)$ and the stiffness of the structure ( $k$ ). The mass constants are obtained by measurement whereas the stiffness constant of the structure is obtained by FEM modeling for open and closed structure models. The results of the analysis will be used to interpret the pattern of failed structures in the development of the diagnostic system. The calculation of damping constant for open and closed model is 0.07556 and 0.12513 , while mass and stiffness constant for closed and open model model is $18 \mathrm{~kg}$ and $9 \mathrm{~kg}$ and $9523809.524 \mathrm{~N} / \mathrm{m}$ and $183486.2 \mathrm{~N} / \mathrm{m}$ for stiffness constant.
\end{abstract}

Keywords : Dynamic Characteristics, Impulse Load, Dynamic Burden, Fast Fourrier Transformation.

\section{PENDAHULUAN}

Jembatan merupakan komponen infrastruktur yang penting dalam moda transportasi. Di Indonesia, jumah jembatan sekitar 89.000 buah atau setara dengan 1050 $\mathrm{km}$ yang tersebar di seluruh wilayah Indonesia (Sukmana dan Vasa, 2012).

Memastikan tingkat keamanan struktur jembatan dalam pengoperasiannya merupakan metode yang harus terus dilakukan. Pada pelaksanaannya hal itu dapat dilakukan dengan observasi visual yang dilakukan secara periodik. Namun dengan metode ini selain tidak akurat karena pola gagal yang diteramati hanya terbatas pada cacat dipermukaan, juga memerlukan waktu yang lama dan sulit dilakukan bila jembatan berukuran besar dan lokasinya sulit dijangkau.

Indentifikasi pola gagal struktur jembatan dengan menggunakan analisis karakteristik dinamik struktur memiliki peluang yang besar untuk memperbaiki kualitas diagnosis maupun secara operasional mudah dilakukan.

Berbagai penelitian untuk menganalisis struktur jembatan akibat beban dinamik lalu lintas kendaraan telah banyak dilakukan, antara lain oleh Memory and Brameld (1995), Yoshimura dkk (2006) dan Zong dkk, (2005). Dalam perkembangan berikutnya, kondisi dinamik suatu struktur digunakan untuk menghitung remaining life (sisa umur) struktur tersebut yang sangat penting untuk memastikan aspek keamanan maupun keputusan investigasi seperti dilakukan oleh Coppolino (2014).

Dalam kaitannya dengan beban pengoperasiannya, prestress pada jembatan berpengaruh pada respon dinamik jembatan pada saat kendaraan melewatinya. Dengan memodelkan jembatan sebagai beam kontinyu dengan prestress eksentrik, sedangkan kendaraan yang melintas diwakili dengan model 4 derajat kebebasan, sebuah model jembatan - kendaraan baru dengan mempertimbangkan pengaruh prestress 
dibuat dengan virtual works. Investigasi respon dari interaksi jembatan - kendaraan dilakukan dan akurasinya divalidasi dengan pemodelan FEM. Didasarkan pada model yang dibuat, simulasi juga dilakukan dengan Newmark integration method untuk mengamati pengaruh studi parametrik terhadap bentang jembatan, panjang bentang, eksentrisitas dan amplitude prestress. Hasil menunjukkan bahwa prestress secara signifikan berpengaruh pada akselerasi vertikal maksimum kendaraan yang dinyatakan dengan indeks yang baik untuk mendeteksi perubahan prestress (Zhong dkk, 2015).

Studi mengenai analisis dinamik gabungan antara kendaraan dan sistem jembatan tiga dimensi di bawah terpaan angin dilakukan oleh Chai dan Chen (2004). Dalam studinya, kendaraan yang melintasi jembatan dimodelkan sebagai suatu rigid body yang terdiri dari blok massa, pegas dan damper. Parameter yang dimasukkan ke dalam proses analisis antara lain berupa kondisi angin dan kondisi jalan. Dalam paper ini juga membahas mengenai pengaruh kecepatan kendaraan terhadap kinerja dinamik jembatan maupun kendaraan yang bersangkutan. Ditemukan bahwa kecepatan kendaraan berpengaruh penting terhadap respon vertical relative kendaraan, tetapi tidak berpengaruh secara signifikan pada respon rolling kendaraan. Respon absolut kendaraan didominasi oleh respon jembatan ketika kecepatan angin tinggi, sedangkan pada kecepatan angin rendah respon absolut kendaraan didominasi oleh kekasaran jalan.
Angin - kendaraan dan sistem jembatan dapat dinyatakan sebagai suatu hasil interaksi dari angin - jembatan, jembatankendaraan dan angin - kendaraan. Penelitian diawali dengan investigasi pembebanan lalu lintas, dimana seluruh parameter kritis seperti jenis kendaraan, bobot, ukuran dan kecepatan direkam dan dianalisa dan diurai sesuai dengan karakteristik statistik. Data tersebut selanjutnya digunakan untuk mensimulasikan keacakan aliran lalu lintas yang akan digunakan sebagai masukan dalam simulasi FEM. Analisis dinamis dari interaksi antara angin - kendaraan dan jembatan dilakukan dengan FEM, dimana jumlah kendaraan yang melintas, jalur yang digunakan dan arah aliran kendaraan merupakan parameter dipertimbangkan. Hasil penelitian menunjukkan bahwa arah aliran lalu lintas berpengaruh kecil pada respon dinamik jembatan. Respon dinamik jembatan terutama ditentukan oleh gerakan beban kendaraan dan komponen fluktuatif dimana respon dinamik tersebut akan meningkat dengan peningkatan kecepatan angin.

Paper ini mempresentasikan penentuan konstanta redaman (c) dari model struktur jembatan yang akan digunakan dalam penentuan persamaan dinamik model jembatan untuk mengembangkan sistem diagnosis pola gagal. Penentuan konstanta peredaman dilakukan dengan memberikan beban impuls pada model. Dari hasil pengukuran getaran (amplitude terhadap fungsi waktu), nilai c dihitung dengan logarithmic decrement seperti ditunjukkan dalam gambar 1 dan persamaan 1 (Widyanto dkk, 2013).

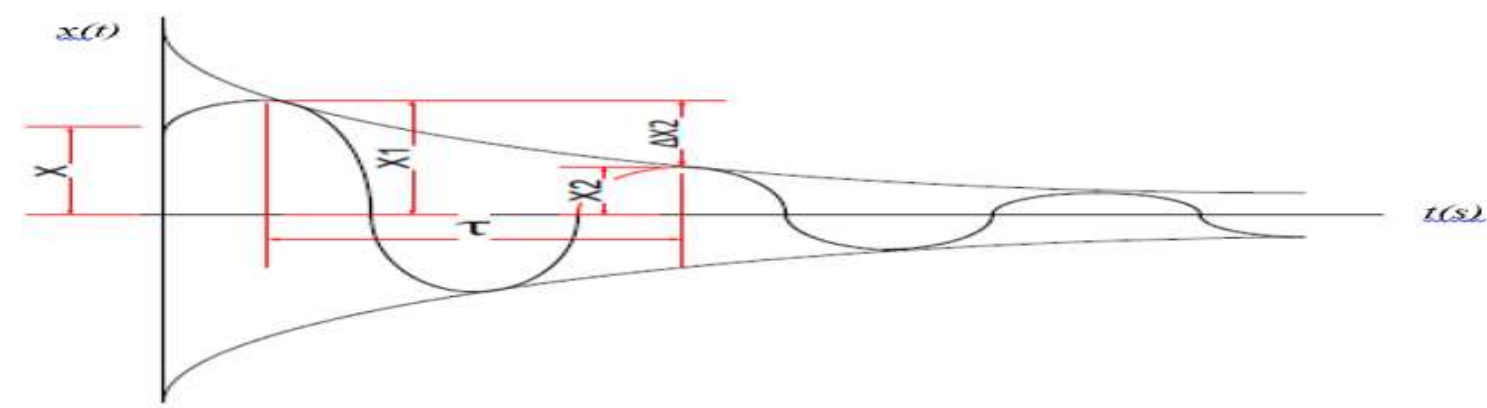

Gambar 1. Kurva Frekuensi Respon Hasil Pengukuran Getaran Akibat Beban Impuls.

(Widyanto dkk, 2013) 
$\delta=\ln \left|\frac{x}{x_{n+1}}\right|$

Dimana :

$\delta \quad=$ Logarithmic Decrement.

$x=$ Amplitudo pada gelombang pertama.

$x_{\mathrm{n}+1}=$ Amplitudo pada gelombang kedua.

Dengan harga logarithmic decrement tersebut, maka konstanta redaman dihitung dengan Persamaan 2 berikut ini :

$c=\frac{\delta}{\sqrt{4 \pi^{2}+\delta^{2}}}$
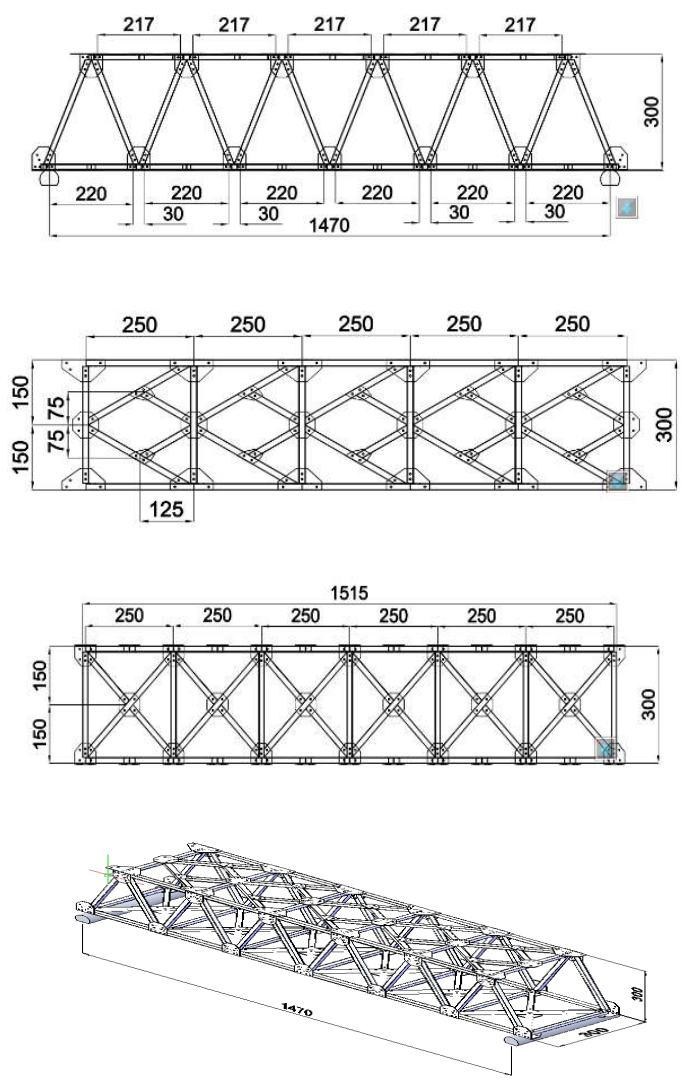

(a)

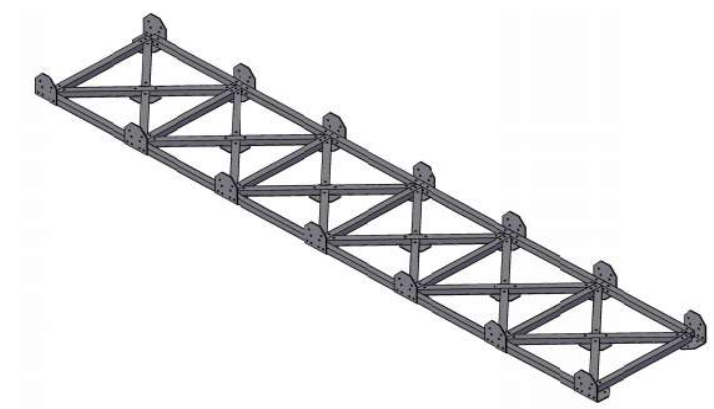

(b)

\section{METODOLOGI PENELITIAN}

Penelitian dilaksanakan secara eksperimental pada model jembatan dengan struktur baja profil hollow $15 \times 15 \mathrm{~mm}$ tebal $2 \mathrm{~mm}$. model struktur jembatan ditumpu pada kedua ujungnya dengan material nylon. Antar komponen struktur dihubungkan dengan plat penghubung setebal $2 \mathrm{~mm}$ yang dibaut dengan masing-masing menggunakan dua buah abut M4. Untuk mewakili bidang jalan, model jembatan menggunakan plat setebal $5 \mathrm{~mm}$ yang dibaut dengan struktur dan dilapisi dengan lembaran karet setebal 2 $\mathrm{mm}$. Dalam penelitian ini dua model struktur jembatan meliputi model dengan struktur tertutup dan struktur terbuka. Dimensi model - model struktur jembatan, kondisi tumpuan dan jenis sambungan antar komponen struktur ditunjukkan dalam gambar 2 .

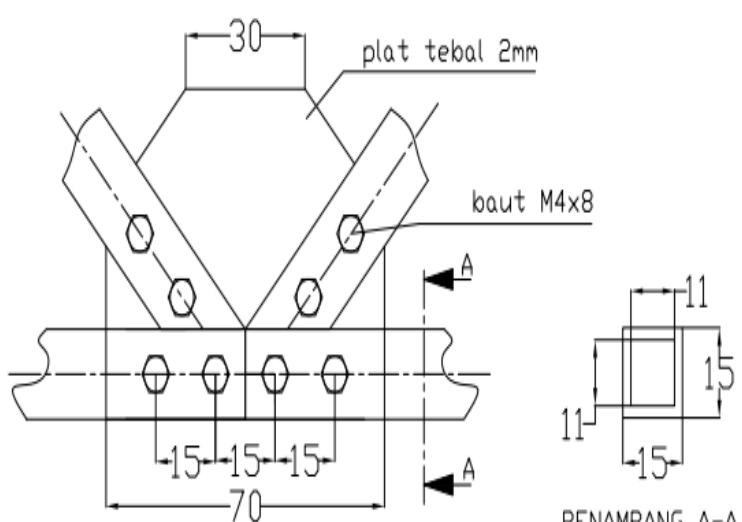

(c)

Gambar 2. Model Struktur Jembatan dan Model Sambungan Antar Komponen Struktur. 
Selanjutnya pengujian dilakukan dengan mengukur modus getar model struktur jembatan akibat stimulasi gaya tunggal (impuls) dan gaya dinamik. Pembebanan gaya tunggal menggunakan modal hammer sedangkan pembebanan dinamis menggunakan model pembeban dinamis yang dapat diatur amplitudo maupun frekuensinya. Kedua jenis pembebanan dilakukan pada lokasi yang sama pada titik beban model jembatan. Model pembeban dinamis yang digunakan seperti ditunjukkan dalam gambar 2, sedangkan set-up pembeban struktur jembatan ditunjukkan dalam gambar 3 .

\subsection{Set-up Pengukuran}

Respon getaran diukur dengan menggunakan dua buah wireless sensor yang diletakkan pada struktur utama jembatan yang masing - masing berjarak $100 \mathrm{~mm}$ dari posisi tumpuan. Posisi sensor pada model jembatan seperti ditunjukkan dalam gambar 4a. Sedangkan pada pengujian peredaman getaran, beban impuls diberikan pada ujung alat bantu. Desain alat bantu pembeban impuls seperti ditunjukkan dalam gambar $4 \mathrm{~b}$.

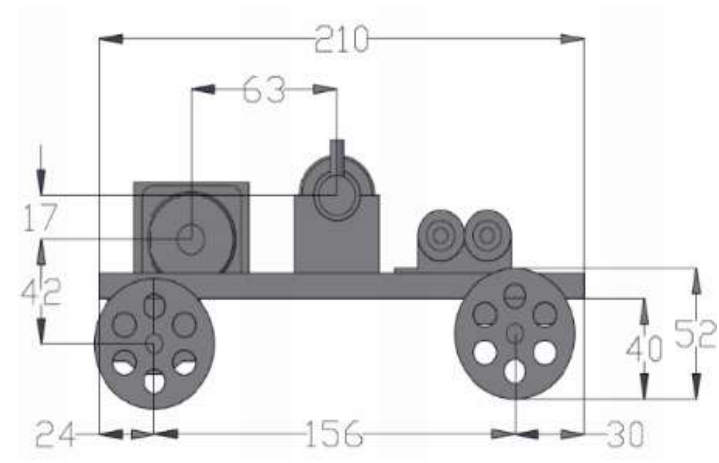

(a)

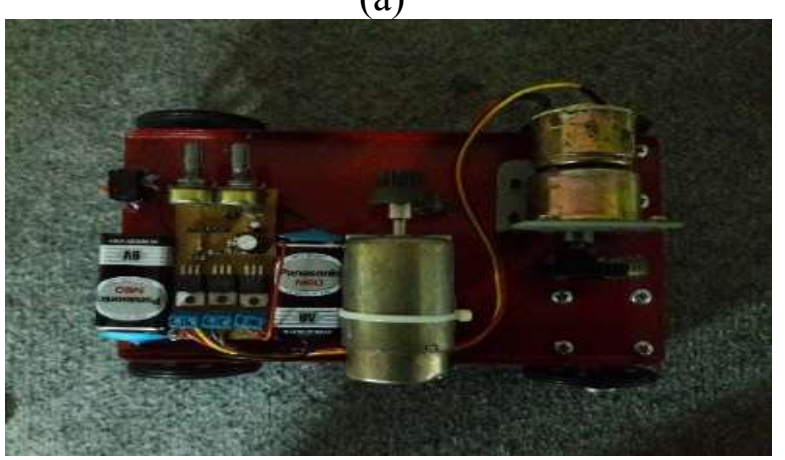

(c)
Untuk pemosisian model pembebanan dinamis ditunjukkan pada gambar 4c. Desain alat bantu pembeban impuls didasarkan pada pola pembeban yang equivalent dengan model pembeban dinamis.

\subsection{Analisis dan Pengolahan Data}

Data hasil pengukuran respon getaran model jembatan akibat beban impuls akan digunakan untuk menghitung konstanta redaman dan fungsi respon getaran. Selanjutnya dengan menggunakan data yang sama, data tersebut dianalisis dengan Fast Fourrier Transfor (FFT) untuk mengobservasi spectrum frekuensi model akibat beban tunggal.

Data hasil pengukuran respon getaran model akibat beban dinamis akan dianalisis dengan FFT. Selanjutnya kedua data FFT akibat beban impuls dan beban dinamis tersebut dibandingkan. Hasil perbandingan tersebut akan dianalisis untuk dikembangkan sebagai dasar prosedur diagnosis struktur jembatan yang berkaitan dengan karakteristik kekakuannya.

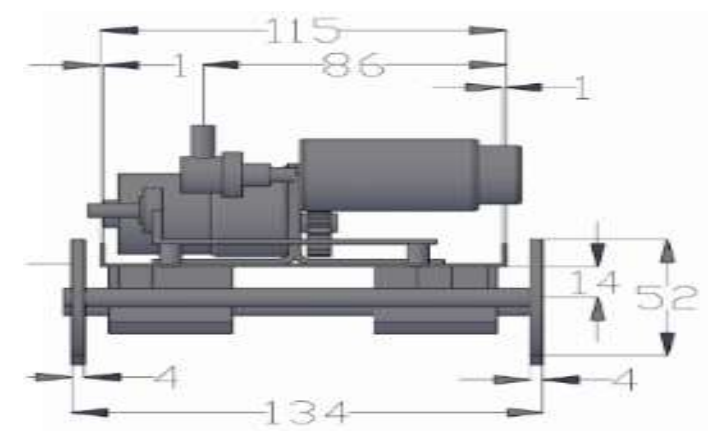

(b)

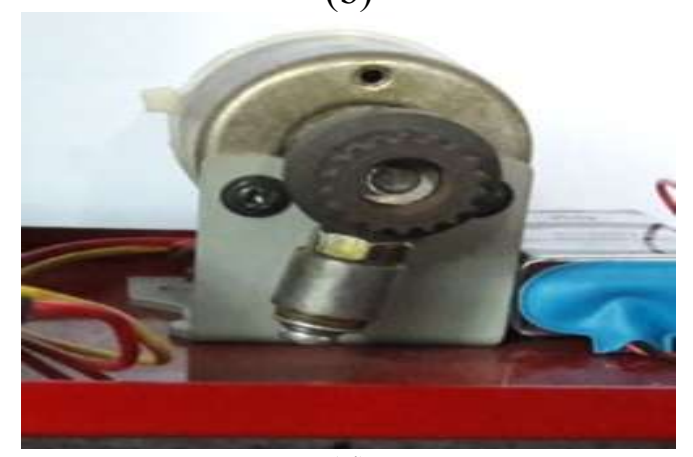

(d)

Gambar 3. Set-up Pembebanan Model Jembatan. 


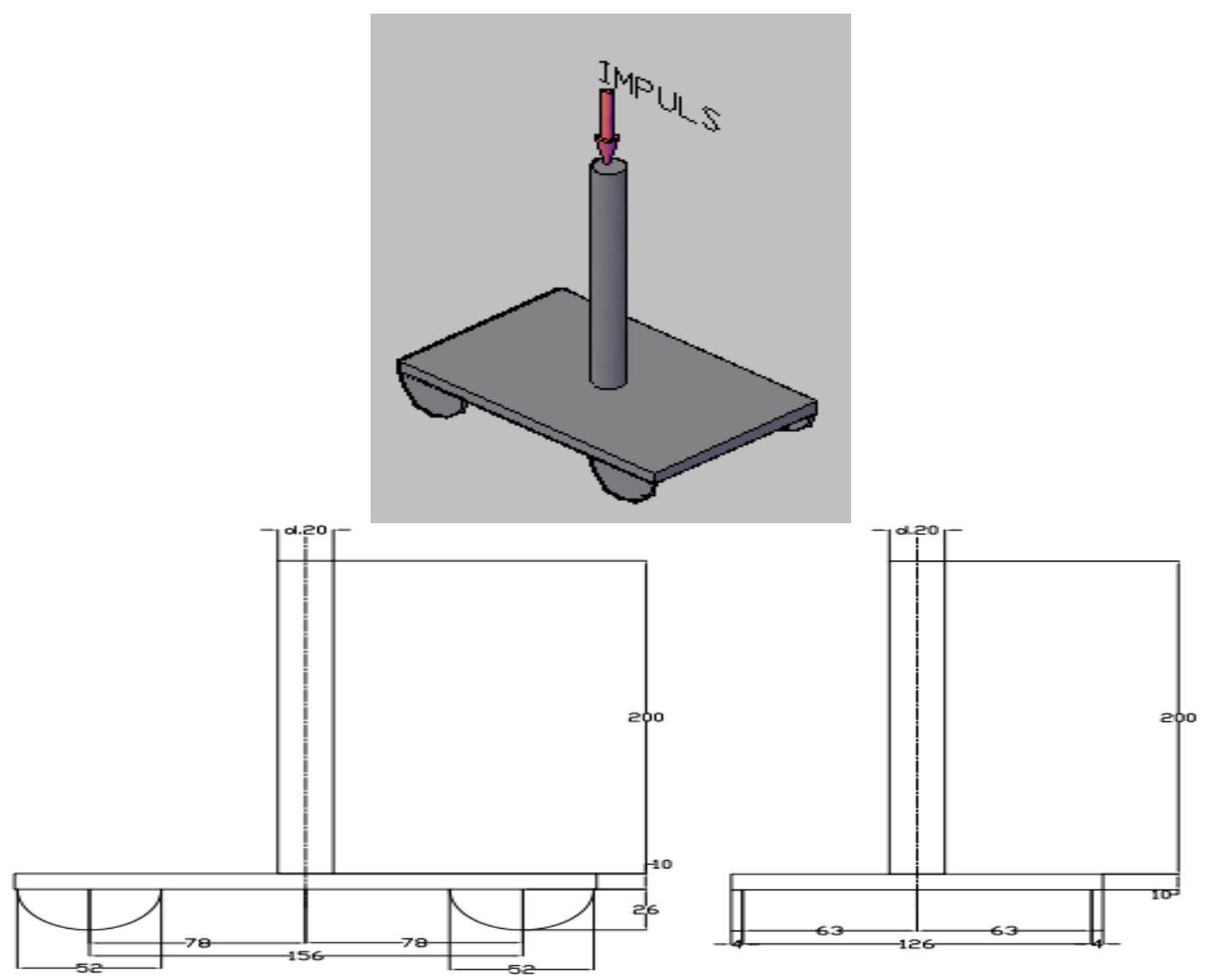

(a)

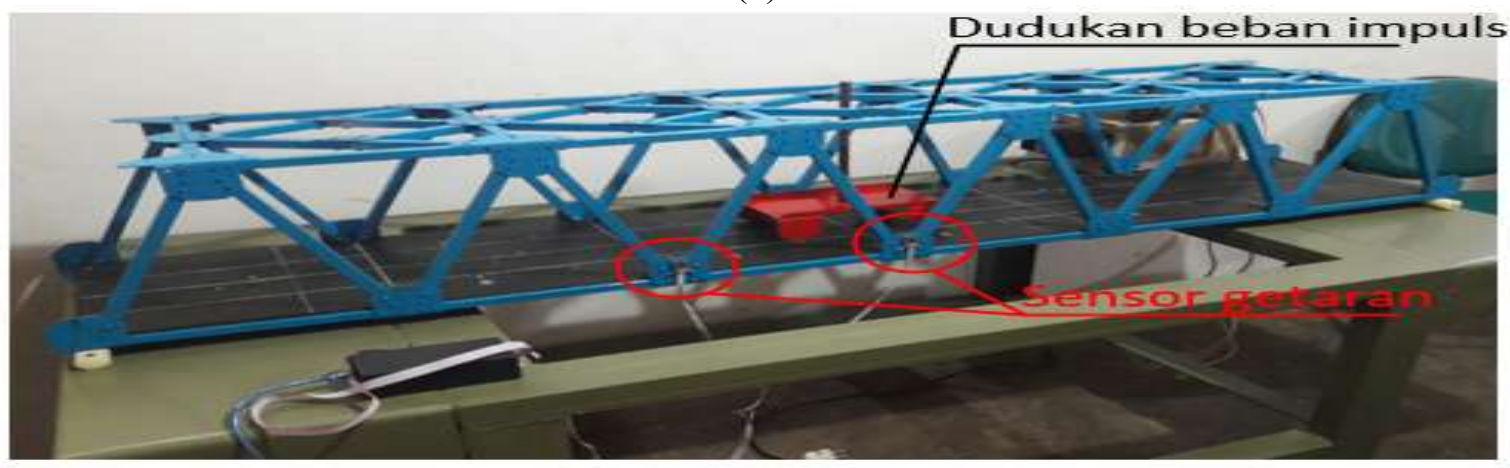

(b)

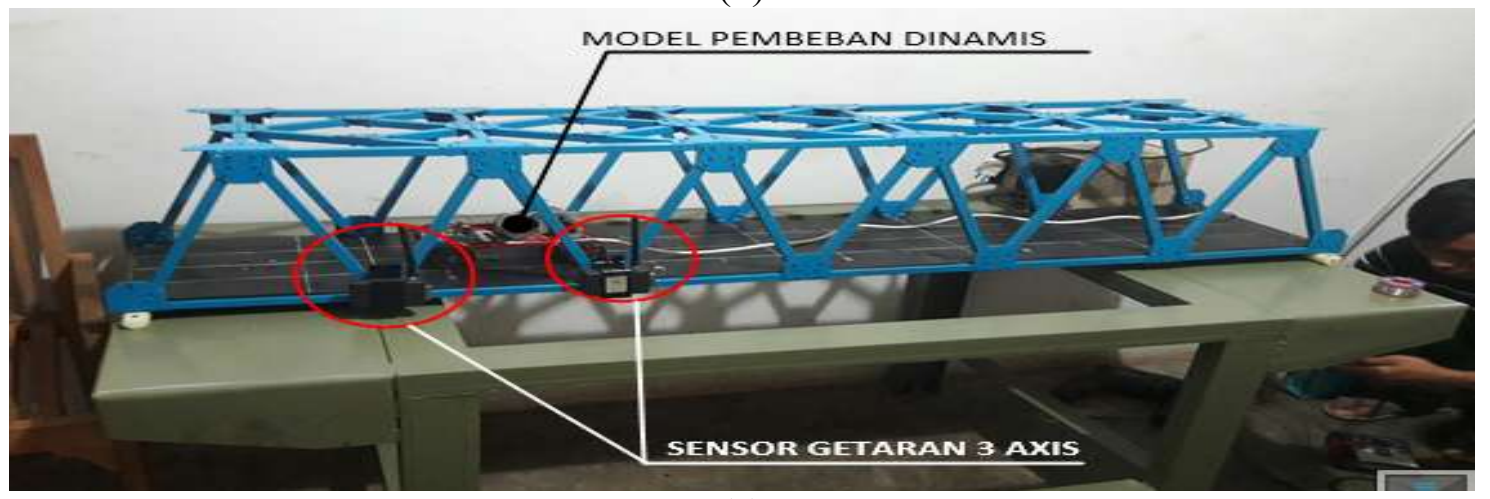

(c)

Gambar 4a. Alat Bantu Pembebanan Impuls Pada Pengujian Peredaman Getaran.

Gambar 4b. Pemosisian Alat Bantu di Tengah Model Struktur Tertutup. Gambar 4c. Pemosisian Model Pembeban Dinamis. 


\section{HASIL DAN PEMBAHASAN}

Metode perhitungan konstanta peredaman dengan logarithmic decrement pada dasarnya dilakukan dengan membandingkan amplitudo getaran pada suatu fase dengan amplitudo getaran pada fase berikutnya. Oleh karena itu perhitungan konstanta peredaman tidak dipengaruhi oleh gaya impuls yang diberikan. Gambar 5 dan 6 menunjukkan kurva respon getaran dari model struktur tertutup dan terbuka yang diuji dengan menggunakan gaya impuls sebesar $12 \mathrm{~N}$.

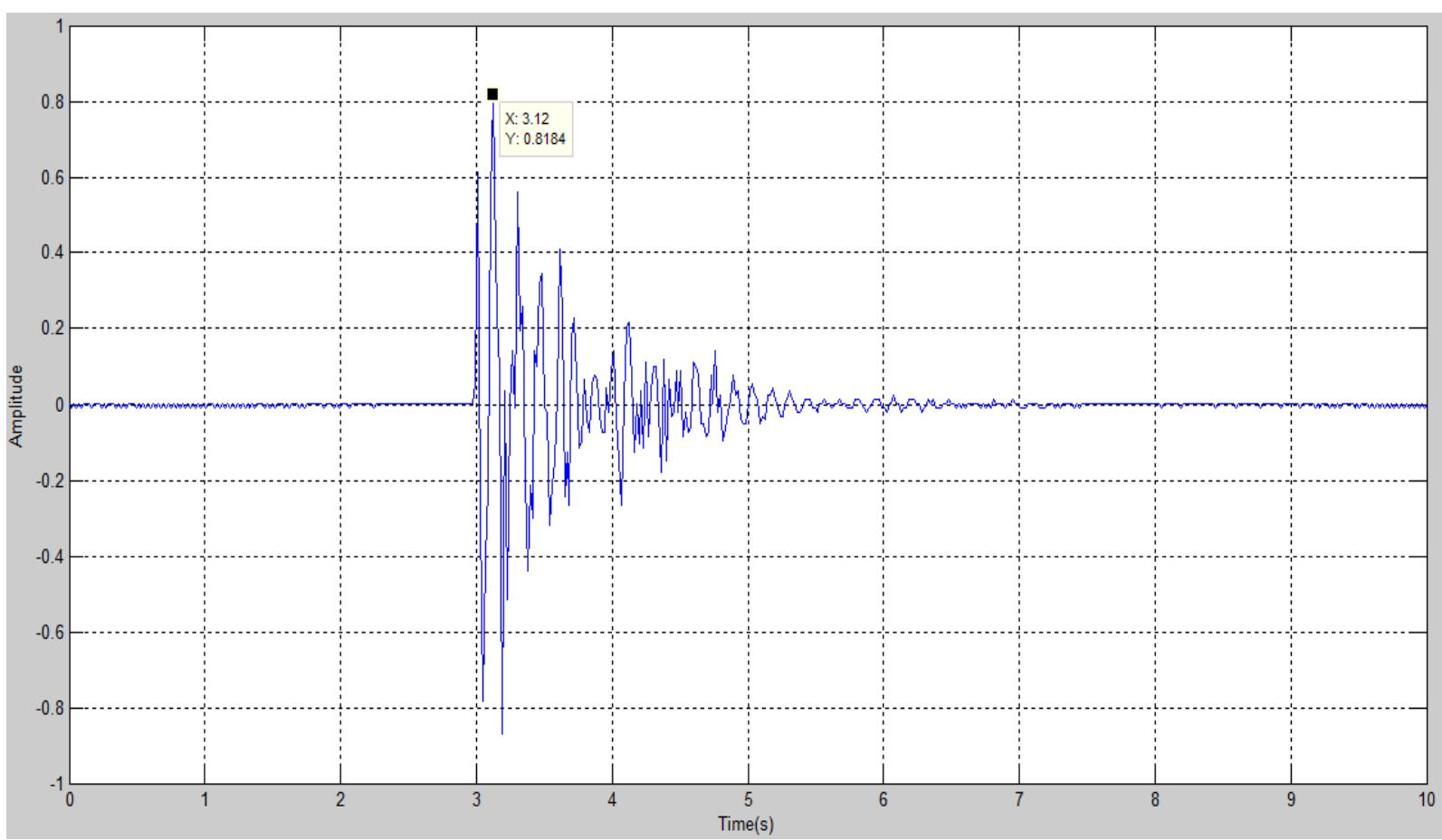

Gambar 5. Hasil Pengukuran Respon Getaran Model Struktur Tertutup dengan Metode Beban Impuls.

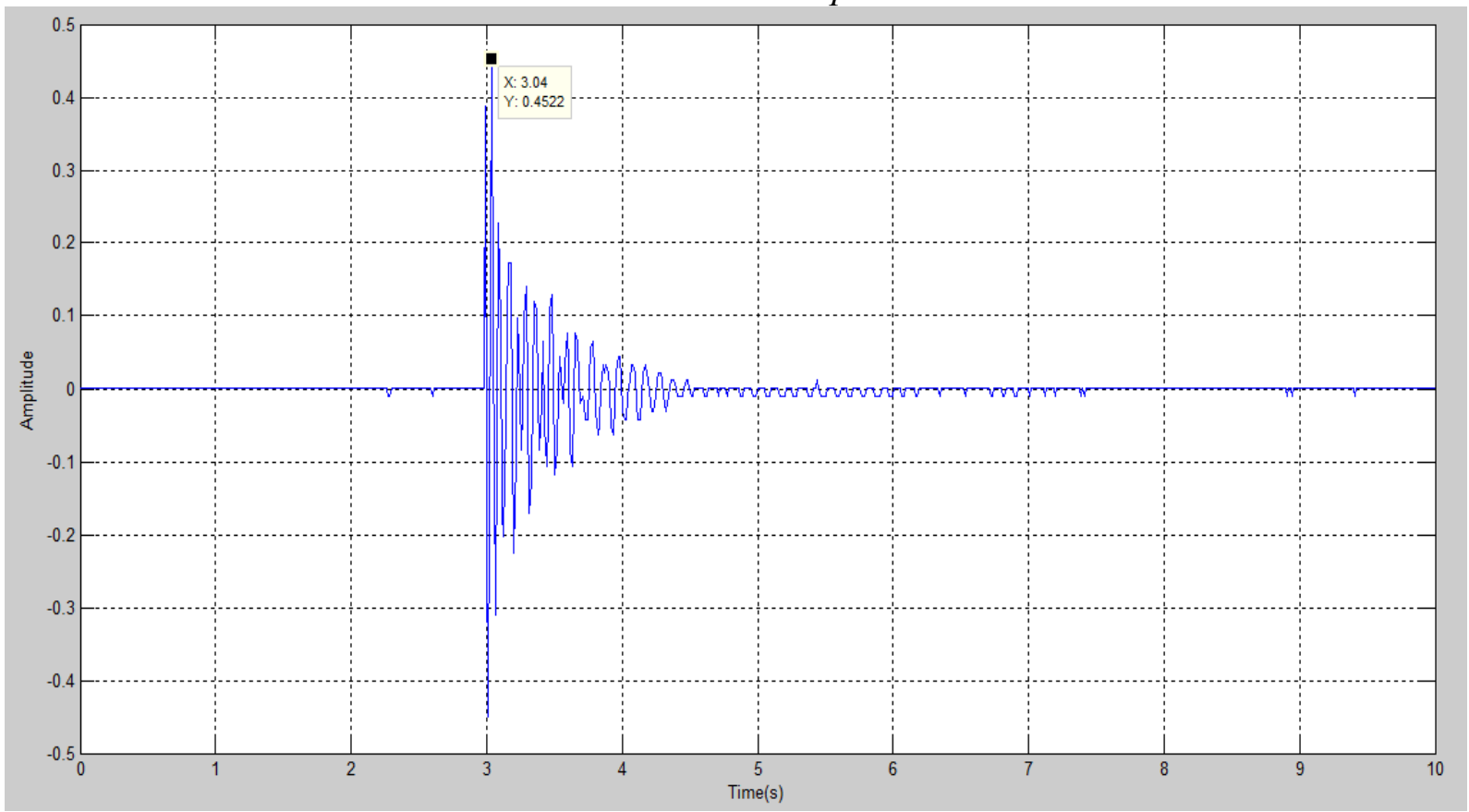

Gambar 6. Hasil Pengukuran Respon Getaran Model Struktur Terbuka Dengan Metode Beban Implus. 
Tabel 1. Perbandingan Nilai Kekakuan dan Redaman

\begin{tabular}{c|c|c|c|c|c}
\hline MODEL STRUKTUR & $\mathbf{X}_{\mathbf{1}}$ & $\mathbf{X}_{\mathbf{2}}$ & $\boldsymbol{\delta}$ & $\boldsymbol{\delta}^{\mathbf{2}}$ & $\mathbf{c}$ \\
\hline Model Struktur Tertutup & 0,4522 & 0,2266 & 0,69094 & 0,4774 & 0,07556 \\
& & & & & \\
Model Struktur Terbuka & 1,02 & 0,4185 & 0,89088 & 0,79367 & 0,12513 \\
\hline
\end{tabular}

Tabel 2. Data - data Pengujian Pembebanan Dinamis

\begin{tabular}{l|c|c}
\hline \multicolumn{1}{c|}{ Data Pengujian } & Nilai & Satuan \\
\hline Massa unbalance & 11,69 & $\mathrm{~g}$ \\
Putaran & 700 & $\mathrm{rpm}$ \\
Kecepatan angular & 73,33 & $\mathrm{Rad} / \mathrm{s}$ \\
Radius putar massa unbalance & 21 & $\mathrm{~mm}$ \\
Gaya sentrifugal & 1.32 & $\mathrm{~N}$ \\
\hline
\end{tabular}

Berdasarkan kurva respon getaran hasil pengukuran tersebut, nilai logarithmic decrement dan konstanta peredaman untuk masing-masing struktur dinyatakan dalam tabel 1. Berdasarkan hasil pensimulasian dengan FEM, model struktur tertutup memiliki kekakuan yang lebih besar dibandingkan model struktur terbuka, tetapi kondisi tersebut berbanding terbaliik dengan karakteristik kemampuan peredamannya.

Secara umum perilaku dinamik struktur struktur dapat di representasikan dengan persamaan diferensial (PD) orde 2 seperti ditunjukkan dalam persamaan 3 dimana koefisien redaman struktur hasil perhitungan diatas merupakan salah satu konstanta (c) yang ada dalam PD tersebut. Untuk dapat menurunkan PD orde 2 tersebut, konstantakonstanta terkait lainnya yaitu massa (m) dan konstanta kekakuan struktur (k) harus diperoleh terlebih dahulu.
Berdasarkan pada PD orde 2 tersebut, beban stimulasi berupa beban dinamik yang disesuaikan dengan kondisi kerja stuktur jembatan, dimana gaya stimulasi berupa gaya dinamis sinusoidal dengan amplitude sebesar F. Mengacu pada model pembeban dinamis yang digunakan sebagai beban stimulasi, F berupa gaya sentrifugal dari massa unbalance seperti ditunjukkan dalam Persamaan 3. Data - data pengujian untuk menghasilkan gaya sentrifugal seperti dinyatakan dalam tabel 2 .

$$
\begin{aligned}
& m \ddot{x}+c \dot{x}+k x=F \sin (\omega t) \text {. } \\
& F=m \omega^{2} r \text {. } \\
& \omega=\frac{2 \pi n}{60}
\end{aligned}
$$

Dimana :

$\mathrm{F} \quad=$ Gaya Sentrifugal $(\mathrm{N})$.

$\mathrm{M} \quad=$ Massa Unbalance $(\mathrm{kg})$.

$\omega \quad=$ Kecepatan Angular $(\mathrm{rad} / \mathrm{s})$.

$\mathrm{R} \quad=$ Radius Putar (m). 
Tabel 3. Data - data Hasil Pengukuran untuk Menentukan Persamaan Dinamik Model Jembatan

\begin{tabular}{c|c|c|c}
\hline MODEL STRUKTUR & M (kg) & c & $\mathbf{k ~ ( N / m )}$ \\
\hline Model Struktur Tertutup & 18 & 0.07556 & 9523809.524 \\
Model Struktur Terbuka & 9 & 0.12513 & 183486.2 \\
\hline
\end{tabular}

Massa struktur jembatan (m) diukur $F=k \cdot x$ dengan timbangan, sedangkan $\mathrm{k}$ diperoleh dengan memodelkan struktur model dengan FEM. Berikut ini hasil pemodelan FEM yang diperoleh untuk model struktur tertutup dan terbuka tersebut. Pembebanan dimodelkan dalam bentuk beban statis sebesar $20 \mathrm{~kg}$ yang diposisikan ditengah struktur. Konstanta kekakuan diperoleh dengan membagi gaya dengan defleksi yang diperoleh dari pemodelan seperti ditunjukkan dalam dalam persamaan 6 .

Dari hasil pemodelan FEM dengan pembebanan static sebesar $20 \mathrm{~kg}$, defleksi maksimum yang terjadi untuk kedua model struktur tertutup dan struktur terbuka adalah sebesar 0,021 $\mathrm{mm}$ dan 1,09 $\mathrm{mm}$ Dengan menggunakan persamaan 5, konstanta ke kakuan kedua jenis jembatan adalah $9523809.524 \mathrm{~N} / \mathrm{m}$ dan $183486.2 \mathrm{~N} / \mathrm{m}$. Data hasil pengukuran dan pemodelan yang merupakan nilai konstanta dalam persamaan dinamik kedua model dinyatakan dalam tabel 3 .

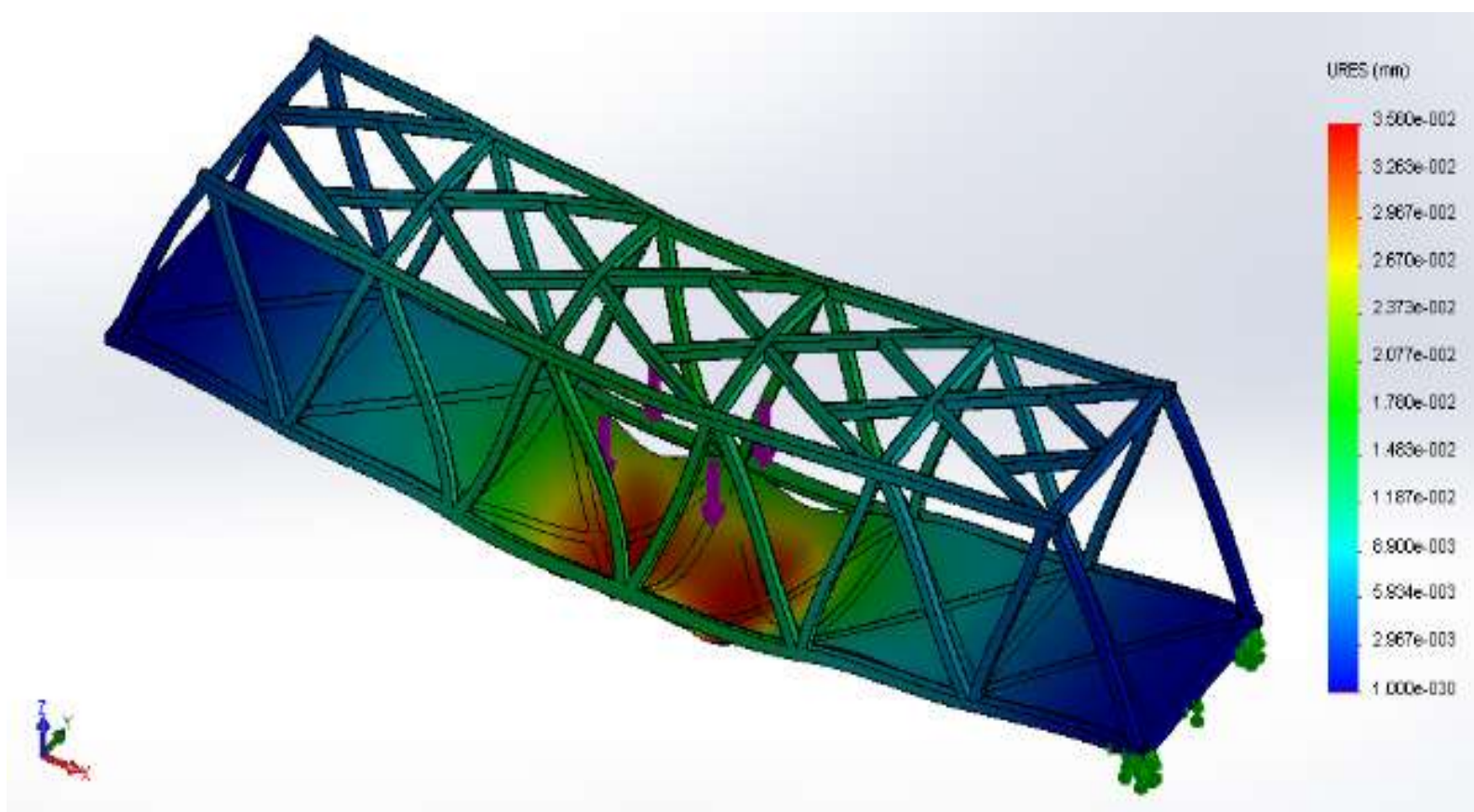

Gambar 7a. Hasil Pemodelan dengan FEM untuk Memperoleh Kontur Defleksi Model Struktur Jembatan dengan Beban Static Sebesar 20 kg. 


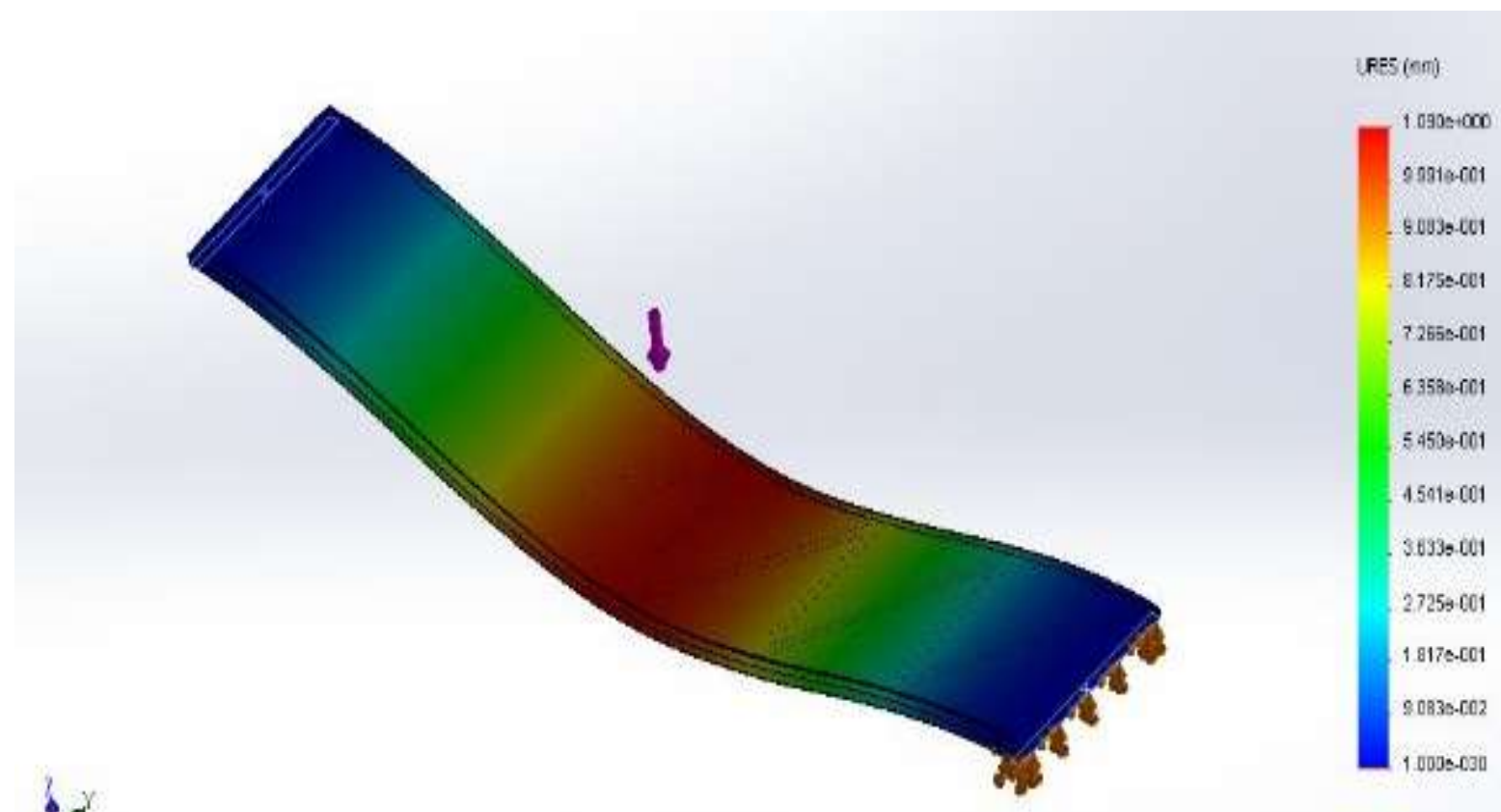

Gambar 7b. Hasil Pemodelan dengan FEM untuk Memperoleh Kontur Defleksi Model Struktur Jembatan dengan Beban Static Sebesar 20 kg.

\section{KESIMPULAN}

Secara eksperimental perhitungan konstanta peredaman model struktur jembatan sudah dilakukan. Hasil pengujian diperoleh bahwa model struktur terbuka memiliki konstanta peredaman lebih besar yaitu 0.12513 dibandingkan model struktur tertutup sebesar 0.07556. Hal tersebut berbanding terbalik dengan konstanta kekakuannya, dimana struktur tertutup memiliki kekakuan yang lebih besar dibandingkan model struktur terbuka yaitu 9523809.524 N/m dan183486.2 N/m. Dari hasil pengukuran getaran juga didapat konstanta redaman model struktur terbuka dan tertutup sebesar 0.07556 dan 0.12513 .

\section{Ucapan Terima Kasih}

Penelitian ini didanai oleh PNBP DIPA Universitas Diponegoro dengan nomor kontrak SP DIPA-042.01.2.400898 / 2016. Penulis mengucapkan terimakasih kepada Vighornes dan Rhomadon atas bantuan mempersiapkan jalannya penelitian ini.

\section{DAFTAR PUSTAKA}

Cai, CS, and Chen, SR., 2004. Framework of vehicle - bridge - wind dynamic analysis, Journal of Wind Engineering and Industrial Aerodynamics, 92, 579-607.

Coppolino, RN, 2014. Structural Dynamic Test-Analysis Correlation, proceeding of the 32nd IMAC, A Conference and Exposition on Structural Dynamics.

Memory, TJ., 1995. Thambiratnam, DP and Brameld, G H, Free vibration analysis of bridges, Engineering Structures, Vol. 17, No. 10, pp. 705 713.

Sukmana, 2012. Vasa,. Jembatan Indonesia sekarang dan mendatang, Direktorat Bina Teknik, Direktorat Jenderal Bina Marga, Departemen Pekerjaan Umum. 
Wang, T., Han, W., Yang, F, and Kong, W., 2014. Wind - vehicle - bridge coupled vibration analysis based on random traffic flow simulation, Journal of Traffic and Transportation Engineering, 1 (4), 293-308.

Widyanto, S. A., Widodo, A., Nugroho, S., \& Siahaan, D., 2013. The effect of geometric structure on stiffness and damping factor of wood applicable to machine tool structure. International Journal of Science And Engineering.

Yoshimura, M., Wu, Q., Takahashi, K., Nakamura, $\mathrm{S}$ and Furukawa, K., 2006. Vibration analysis of the Second Saikai Bridge-a concrete filled tubular (CFT) arch bridge, Journal of Sound and Vibration 290, 388-409.

Zhong, H., Yang, M, and Gao, ZJ., 2015. Dynamic responses of prestressed bridge and vehicle through bridgevehicle interaction analysis, Engineering Structures, 87, 116125. 